\title{
University of Port Harcourt Student-Teachers' Self-Determination and Hindrances Towards Learning Online During COVID-19
}

\author{
Sandra Eberechukwu Augustine ${ }^{1 *}$ (1), Ebere Pearl Ezeoguine ${ }^{1}$ ()
}

${ }^{1}$ Department of Curriculum Studies and Educational Technology, Faculty of Education, University of Port Harcourt, NIGERIA *Corresponding Author: sandra.augustine@uniport.edu.ng

Citation: Augustine, S. E., \& Ezeoguine, E. P. (2022). University of Port Harcourt Student-Teachers' Self-Determination and Hindrances Towards Learning Online During COVID-19. Mediterranean Journal of Social \& Behavioral Research, 6(1), 3-11. https://doi.org/10.30935/mjosbr/11466

\begin{abstract}
This analytical survey focused on investigating the level of student-teachers' self-determination towards learning online during COVID-19 at the University of Port Harcourt and the hindrances they experienced. Two objectives and six hypotheses guided the study. The population was two thousand, seven hundred and sixty-seven $(2,767)$ student-teachers in the Faculty of Education with a sample size of six hundred and twelve (612) drawn randomly from the population. The study gathered data using the researchers' developed questionnaire with a 0.76 alpha reliability coefficient. Data analyses were through mean, standard deviation, t-test, and Welch test. The results disclosed that the University of Port Harcourt student-teachers' self-determination level to learning online during COVID-19 was high; this varies significantly based on study years, departments and gender. Lecturers' inability to develop online courses and distractions during learning online, among others, were the hindrances that affected the student-teachers' self-determination towards online learning during the COVID-19 pandemic. These hindrances vary significantly based on the student-teachers' study years and departments but were insignificant on a gender basis. Among the recommendations were that the University of Port Harcourt should train its lecturers to develop online courses and deliver them through Learning Management Systems dedicated solely for online learning purposes.
\end{abstract}

Keywords: Self-determination, motivation, COVID-19, online learning, hindrances, student-teachers

Received: 8 Oct. $2021 \bullet$ Accepted: 29 Nov. 2021

\section{INTRODUCTION}

Most students enter university with diverse expectations. Some students may have the goal of graduating with good grades, either firstclass or second-class upper division. Some of these students may work hard to obtain Alpha (A) or Beta (B) with fewer Credits (C) in their course grades to achieve their targets, while others may exhibit a nonchalant attitude towards their original ambitions. Students tend to study hard to actualize their dreams when they are in comfortable situations. Events and circumstances can contribute to students' decisions to pursue their set goals in life or not. An ugly situation like the COVID-19 pandemic can be the highest demoralization factor that leads to students losing focus without putting inadequate efforts into their studies. In such a situation that keeps people indoors, students may need to be resolute and continue learning using online courses and resources available on the Internet.

Students' self-determination to learn and succeed in their careers can motivate them to explore different means and educational resources to keep learning and improve themselves academically, whether at home or in an academic environment. Self-determination is someone's willingness to set goals, act and make good resolutions that lead to the goals' realization. Self-determination refers to personal freedom of choice of action or state of achieving set goals without being compelled externally (Merriam-Webster's Dictionary, 2018). Individuals are, sometimes, driven internally to perform actions based on the values, curiosity, enjoyment, or interest they have in those things. Yet, others may act due to external forces like grades, rewards, promotion, and punishments. Self-determination leads to someone's discretion to take the right decision at the right time; it stimulates hard work, active engagement, confidence, and a sense of direction in any chosen task. Heutagogy (self-determined learning) implies a learner-centered teaching method that results in learners' ability, capacity, and autonomy development, with teachers facilitating students' learning by providing guidance and links to learning materials (UNESCO, 2020).

Doll et al. (1996), cited in Vialu (2018), stated that selfdetermination, like other skills, can be learned or develop naturally in people. Vialu (2018) further noted that an individual develops selfdetermination attitudes and skills by setting goals and priorities, making good choices, performing leadership roles, solving problems, adapting to diverse environmental situations, being aware of strengths and weak points, and believing in his capability to achieve set goals. 
National Deaf Center on Postsecondary Outcomes (NDC) (2020) averred that self-determined individuals solve problems and reach their set targets at home or in school, even amid difficulties.

Students' determination to learning focused on self-determination theory. Edward Deci and Richard Ryan propounded the selfdetermination theory in the middle of the 1980s. Self-determination theory identifies the motivational elements that trigger people's choices and recognises two forms of motivation: intrinsic and extrinsic motivations (David, 2014; Neutrino, 2012). Intrinsic motivation refers to the internal motives that instigate people to actions, while extrinsic motivation refers to task execution due to outward benefits. To be selfdetermined implies to be intrinsically motivated to achieve a goal. The self-determination theory helps instructors address the three fundamental and psychological needs, such as competency, autonomy, and relatedness, to promote intrinsic motivation. Based on the theorists' perspective, competence implies the ability to take charge of the mastery of different experiences; relatedness implies the general desire for interaction, connection, and consideration for other people; while autonomy refers to the need of being responsible for one's actions, choosing among different alternatives, taking control over one's life as well as acting in agreement with one's desires. Meeting these needs may help instructors create opportunities for students' selfdetermination, which leads to optimal learning and performance. UNESCO (2020) asserted that technology integration into online learning causes students to develop an interest in self-determined learning.

According to Bates (2016), online learning may not have an official definition, but scholars defined it on assumptions. College SA (2017) avers that online learning implies course enrollment and learning using videos and assessments with an Internet connection. Bates (2016) defines online learning as education that occurs partially or totally through the Internet. Online learning involves learning through the Internet-enabled learning platforms with or without a planned educational curriculum. Most Institutions run total or blended online education as an instructional delivery model based on their school curriculum. Some institutions and non-governmental organizations develop online courses to help learners acquire skills and knowledge outside the school curriculum. Online learning with a planned education curriculum is accessible only to all the duly admitted students in an institution. Unplanned curriculum online learning occurs as Massive Open Online Courses (MOOCs) for any interested learners. Dave Cormier developed the MOOC concept in 2008 (NOVA Southeastern University, 2020). MOOCs and other resources on the Internet broaden a learner's opportunity to continue learning whether or not his institution engages in online education.

Online learning focuses on learners' independence, flexibility, and less supervision by instructors. Learning online requires learners to study course content and resources and participate in learning activities and assessments at their convenience, location, and learning speed. This freedom may pose some problems to students with low selfdetermination and motivation to learn. Since the online world has many distractions that might reduce students' concentration level during learning, participating in and completing online learning tasks during COVID-19 may depend on students' self-determination.

COVID-19 is a dreaded disease that infested the whole world from the first quarter of 2020, leading to the shutdown of every life activity. Schools and businesses were drastically affected and put on hold as people stay indoors to stay safe from the disease as recommended by the World Health Organization (WHO). Academic activities stopped physically, and online education was the viable alternative for schools to remain open to students' learning. The report shows that above 12.2 billion students study from home globally during the COVID-19 period (Li \& Lalani, 2020). Schools with online educational facilities switched swiftly to online learning mode with their students learning from home. Observations showed that most higher institutions in the developing countries that practiced only conventional education were unprepared for the sudden transition to an online learning model due to digital infrastructural deficit and poor teachers' technical competency. The COVID-19 incidence mandated most developing nations' higher institutions to deploy online instructional platforms and start compulsory online workshops to train teachers on online instructional delivery procedures. Although with unexpected curriculum change, Gustiani (2020) reported that during the COVID19 pandemic, educators exposed students to different online learning applications and conducted lectures through conferencing tools such as Mikogo, Google Meet, WebEx, and Zoom.

The Nigerian Ministry of Education directed higher institutions to commence online learning as a COVID-19 safety measure (Alli, 2020). Many states in Nigeria also started radio and television programmes; to help students in lower educational levels to continue learning while staying indoors. Online education was not a general practice at the University of Port Harcourt before the COVID-19 pandemic; however, the Educational Technology lecturers in the Faculty of Education started using online learning platforms like Edmodo, Google Classroom, and social media in a blended approach to teach the Computer in Education course since 2017. Although, the strike action by the Academic Staff Union of Universities, which started 6th March 2021 and ended 23rd December 2021, halted the 2019/2020 academic activities in the Nigerian federal universities. After school resumption on the 11th January 2021, the University of Port Harcourt responded to the need for online learning transition due to COVID-19 by training its lecturers to use the Google Educational Suite (Google Classroom and Google Meet); and Zoom Cloud Meeting for full online instructional delivery. Students received lectures through voice notes, video recordings, audio/video conferencing, submitted assignments, and interacted with their lecturers online but had a face-to-face examination to complete the first semester of the 2019/2020 academic session, which ended 1st April 2021. At the commencement of the second semester, the University of Port Harcourt gave its lecturers the option of choosing between online and physical classroom instructional delivery modes. Observation showed that most Lecturers resorted to the physical classroom instructional delivery modes.

Despite the interventions by some schools and state governments to bridge the gap created by COVID-19 to students' learning, some students may still be unable to learn. Carr et al. (2020), cited in Sivrikova et al. (2021), remarked that people experienced future uncertainties, boredom, anxiety for death, disappointments, and frustrations owing to unmet expectations during the COVID-19 lockdown. Some students may have difficulties coping with the online education introduced by some higher institutions, owing to the challenges characterized by digital learning. Others may be naturally unwilling to engage in any academic activities, possibly due to lack of self-determination and depression caused by the COVID-19 pandemic. 
Understanding the rate at which students were self-determined to engage in online learning activities during the COVID-19 period and beyond will help university instructors and administrators to develop and implement strategies to enhance self-determination in students. Nissman (2020) avers that instructors should help distance learning students build self-determination skills like goal-setting, selfmonitoring, choice-making, and problem-solving skills to equip them for the future. UNESCO (2020) remarks that developing learning abilities and reinvention is people's utmost life desire. To foster students' self-determination in online learning, instructors may need to encourage students to write out their expectations for each course, share those expectations with other students and their instructors, choose appropriate learning experiences and monitor their progress towards achieving those expectations.

Some researchers conducted studies related to students' online learning participation and barriers during the COVID-19 pandemic. For instance, Batmang et al. (2021) investigated how student-teachers in Arab perceived online education during the COVID-19 pandemic. Using interviews and observations: their findings indicated that the student-teachers perceived that self-determination, stimulation, connectivity, and competence were the online learning requirements. Gustiani (2020) studied the English students' online learning motivation amid the COVID-19 pandemic at the Sriwijaya Polytechnics and found the students were motivated internally to engage in the online study because they desire new knowledge and enjoy their novel learning experiences; however, poor infrastructure led to the students' poor online learning motivation. Agbejule et al. (2021) investigated elements that motivated and hindered Vaasa University students' online learning participation. They analyzed data with factor and descriptive analyses and found that the online delivery mode caused many students to participate in online learning. Some students reported that their online learning participation was motivated because they were afraid of being left behind. Their online learning hindrances were social interaction and instructional related. Balakrishnan and Long (2020) analyzed the engineering students' motivation in using the WhatsApp platform, a personalized environment for learning in the COVID-19 era. They found that the students were intrinsically motivated and selfdetermined to learn through the instructional platform.

Onyema et al. (2020) assessed the COVID-19 pandemic educational impact. Their study revealed students' and teachers' reliance on the Internet for learning continuity amid the pandemic, with hindrance due to inadequate facilities, power supply, network, and technical skills. Sari and Nayir (2020) studied the challenges and way forward the lecturers and administrators perceived using eLearning during the COVID-19 pandemic. Their findings revealed were infrastructural, internet access, classroom management, and students' and teachers' behavioural problems. Sari and Nayir (2020) reported that professionals, family members, peers' assistance, effective classroom management, and improving parents' and students' communication would help tackle the listed challenges. Mbunge et al. (2021) investigated the factors that influence Computer students' online learning performance and found that apart from the COVID-19 challenge, lecturers' online teaching competency, poor Internet access and availability, technology literacy, self-motivation and discipline, among others affected the students' performance negatively.

Although there is much research evidence on students' participation in online learning during the COVID-19 pandemic, none has established the level of students' self-determination to continue learning during the pandemic period and beyond in the University of Port Harcourt. This identified gap led the researchers to investigate the extent to which the University of Port Harcourt student-teachers were self-determined to learn online during the COVID-19 Pandemic the hindrances that may interfere with students' self-determination; with suggestions that will project determination attitudes towards learning online among student-teachers.

Objectives of the Study

This study soughts to:

1. find out the level of University of Port Harcourt studentteacher self-determination towards learning online during the COVID-19 pandemic and

2. determine the hindrances that may affect University of Port Harcourt student-teachers' self-determination towards online learning during the COVID-19 pandemic.

Hypotheses (Tested at 0.05 Significant Level)

1. The University of Port Harcourt student-teachers' level of selfdetermination towards learning online did not vary significantly during the COVID-19 pandemic based on the study year.

2. The University of Port Harcourt student-teachers' level of selfdetermination towards learning online did not vary significantly during the COVID-19 pandemic based on department.

3. The University of Port Harcourt student-teachers' level of selfdetermination towards learning online did not vary significantly during the COVID-19 pandemic based on gender.

4. The University of Port Harcourt student-teachers' selfdetermination hindrances to learning online did not vary significantly during the COVID-19 pandemic based on study year.

5. The University of Port Harcourt student-teachers' selfdetermination hindrances to learning online did not vary significantly during the COVID-19 pandemic based on department.

6. The University of Port Harcourt student-teachers' selfdetermination hindrances to learning online did not vary significantly during the COVID-19 pandemic based on gender.

\section{METHODOLOGY}

\section{Research Design}

The study adopted an analytical survey design to investigate student-teacher online learning self-determination during the COVID19 pandemic and hindrances.

\section{Study Population}

The study population consisted the 2,767 student-teachers in the Faculty of Education (from Library and Information Science (LIS), Adults and Non-Formal Education (DAE), Curriculum Studies and Educational Technology (EDC), Educational Psychology (EDP), Educational Management (EDM), Educational Foundation (EDF) and Early Childhood and Primary Education (ECPE) departments) at the 
University of Port Harcourt in the 2019/2020 learning session (Source: Faculty of Education Record, 2021).

\section{Sample and Sampling Technique}

The study used a 612 sample size (n) selected through random sampling technique.

\section{Instrumentation}

The researchers used a self-developed instrument called Questionnaire on Self-Determination to Learning Online (QSDLO) for data collection. QSDLO had three sessions. Session 1, 2, and 3 measured student-teacher personal data, objectives 1 and 2, respectively. Session 2 and 3 had four-scale ratings of Very High Level (VHL), High Level (HL), Low Level (LL), and Very Low Level (VLL); and Strongly Agreed (SA), Agreed (A), Disagreed (D) and Strongly Disagreed (SD), respectively. Their weightings were $\mathrm{VHL}$ or $\mathrm{SA}=4, \mathrm{HL}$ or $\mathrm{A}=3$, $\mathrm{LL}$ or $\mathrm{D}=2$, and VLL or $\mathrm{SD}=1$. The weightings criterion point is 2.50 , which served as the basis for agreement or disagreement of each item statement. The instrument underwent face and content validation from two Educational Technology lecturers in the Department of Curriculum Studies and Educational Technology of the same University of Port Harcourt, whose corrections improved the instrument's quality. The instrument's reliability testing was through the Cronbach alpha method, which yielded a 0.76 alpha reliability coefficient.

\section{Data Collection Procedure}

The researchers created a Google form of the questionnaire and administered it to the student-teachers via their departmental Whatsapp group platforms with the help of one of the lecturers from the various departments in the Faculty of Education. The researchers collated the responses from the Google sheet and subjected them to data analyses.

\section{Analyses Techniques}

Mean and standard deviation analysed the research objectives 1 and 2. The Welch test served as the statistics to test hypotheses $1,2,4$, and 5 , while the t-test assisted in testing hypotheses 3 and 6 . The Welch test is an alternative to ANOVA when the assumption on the homogeneity of variance or equal variance is not met (see Appendix A).

\section{RESULTS}

\section{Objective 1}

Objective 1 is to find out the level of University of Port Harcourt student-teachers' self-determination towards learning online during the COVID-19 pandemic. Table 1 shows the mean statistics of students' self-determination to learning online. Table 1 reveals that the studentteachers at the University of Port Harcourt agreed to items numbers 1 to 7 with mean values higher than the 2.50 criterion mean and disagreed with item number 8 with a mean value lower than 2.50 criterion mean value. Generally, the student-teachers' level of self-determination towards learning online during the COVID-19 pandemic at the University of Port Harcourt was high, even though they could not communicate online with their lecturers.

\section{Objective 2}

Objective 2 is to determine the hindrances that may affect University of Port Harcourt student-teachers' self-determination towards online learning during the COVID-19 pandemic. Table 2 shows the mean statistics of students' self-determination hindrances to learning online. Table 2 discloses that the student-teachers at the University of Port Harcourt agreed to items numbers 11, 14, and 15 with mean values higher than the 2.50 criterion mean and disagreed to items numbers $9,10,12$, and 13 with mean values lower than the 2.50 criterion mean. Generally, the student-teachers at the University of Port Harcourt agreed that some hindrances affected their self-

Table 1. Mean statistics of students' self-determination to learning online

\begin{tabular}{|c|c|c|c|c|c|c|c|c|}
\hline Items & VHL & HL & LL & VLL & $\mathbf{n}$ & Mean & S. dev. & Decision \\
\hline \multicolumn{9}{|l|}{ During this COVID-19 period } \\
\hline I am self-determined to pursue my set career goals by learning online & 225 & 277 & 88 & 22 & 612 & 3.15 & 0.79 & Agreed \\
\hline I am self-determined to participate in online learning activities & 220 & 258 & 106 & 28 & 612 & 3.09 & 0.84 & Agreed \\
\hline I am self-determined to complete any online learning course I enroll in & 220 & 257 & 111 & 24 & 612 & 3.10 & 0.83 & Agreed \\
\hline My online academic pursuit is my proirty & 167 & 251 & 157 & 37 & 612 & 2.90 & 0.87 & Agreed \\
\hline I explore different online materials to support my learning & 273 & 238 & 78 & 23 & 612 & 3.24 & 0.82 & Agreed \\
\hline My online study habit has increased & 169 & 273 & 124 & 46 & 612 & 2.92 & 0.88 & Agreed \\
\hline I collaborate online with my course-mates to solve course-related problems & 172 & 226 & 147 & 67 & 612 & 2.82 & 0.96 & Agreed \\
\hline I communicate online with my lecturers. & 85 & 126 & 210 & 191 & 612 & 2.17 & 1.02 & Disagreed \\
\hline Grand mean & & & & & & 2.92 & & High \\
\hline
\end{tabular}

Table 2. Mean statistics of students' self-determination hindrances to learning online

\begin{tabular}{|c|c|c|c|c|c|c|c|c|}
\hline Items & SA & $\mathbf{A}$ & $\mathbf{D}$ & SD & $\mathbf{n}$ & Mean & S.dev. & Decision \\
\hline \multicolumn{9}{|l|}{ During this COVID-19 period } \\
\hline My institution did not participate in online education & 104 & 178 & 246 & 84 & 612 & 2.49 & 0.93 & Disagreed \\
\hline My lecturers did not create online platforms for class communication and collaboration & 117 & 128 & 267 & 100 & 612 & 2.43 & 0.98 & Disagreed \\
\hline My lecturers did not develop online courses & 147 & 168 & 214 & 83 & 612 & 2.62 & 0.99 & Agreed \\
\hline I was not familiar with online learning platforms & 89 & 161 & 247 & 115 & 612 & 2.37 & 0.95 & Disagreed \\
\hline I do not like to participate in online learning & 76 & 112 & 268 & 156 & 612 & 2.18 & 0.95 & Disagreed \\
\hline High cost of data subscription to explore online learning materials & 328 & 209 & 47 & 28 & 612 & 3.37 & 0.81 & Agreed \\
\hline I easily get distracted when learning online & 141 & 190 & 204 & 77 & 612 & 2.65 & 0.97 & Agreed \\
\hline Grand mean & & & & & & 2.59 & & \\
\hline
\end{tabular}


Table 3. Welch test on student-teachers' level of self-determination towards learning online during the COVID-19 pandemic based on study year

\begin{tabular}{|c|c|c|c|c|c|c|c|c|}
\hline Study year & $\mathbf{n}$ & Mean & S.dev. & Statistics $^{\mathrm{a}}$ & df1 & df2 & p-value & Decision \\
\hline YR 1 & 137 & 25.03 & 5.329 & \multirow{5}{*}{9.960} & \multirow{5}{*}{3} & \multirow{5}{*}{262.091} & \multirow{5}{*}{0.00} & \multirow{5}{*}{ Rejected } \\
\hline YR 2 & 270 & 22.38 & 5.487 & & & & & \\
\hline YR 3 & 80 & 24.63 & 4.175 & & & & & \\
\hline YR 4 & 125 & 23.05 & 3.862 & & & & & \\
\hline Total & 612 & 23.40 & 5.112 & & & & & \\
\hline
\end{tabular}

${ }^{\mathrm{a}}$ Asymptotically F distributed

Table 4. Welch test on student-teachers' level of self-determination towards learning online during the COVID-19 pandemic based on department

\begin{tabular}{|c|c|c|c|c|c|c|c|c|}
\hline Department & $\mathbf{n}$ & Mean & Std.dev. & Statistics $^{\mathbf{a}}$ & df1 & df2 & p-value & Decision \\
\hline LIS & 52 & 27.92 & 4.834 & \multirow{8}{*}{13.668} & \multirow{8}{*}{6} & \multirow{8}{*}{247.150} & \multirow{8}{*}{0.00} & \multirow{8}{*}{ Rejected } \\
\hline DAE & 88 & 21.57 & 6.463 & & & & & \\
\hline EDC & 104 & 24.46 & 4.317 & & & & & \\
\hline EDP & 72 & 22.67 & 3.922 & & & & & \\
\hline EDM & 100 & 23.20 & 4.597 & & & & & \\
\hline EDF & 110 & 24.20 & 4.133 & & & & & \\
\hline ECPE & 86 & 21.09 & 5.007 & & & & & \\
\hline Total & 612 & 23.40 & 5.112 & & & & & \\
\hline
\end{tabular}

${ }^{a}$ Asymptotically F distributed

Table 5. t-test analysis of student-teachers' level of self-determination towards learning online during the COVID-19 pandemic based on gender

\begin{tabular}{ccccccccc}
\hline Gender & $\mathbf{n}$ & Mean & S.dev. & $\begin{array}{c}\text { Mean } \\
\text { difference }\end{array}$ & df & t & p-value & Decision \\
\hline Male & 190 & 24.91 & 4.86 & 2.19 & 610 & 4.99 & $\mathbf{0 . 0 0}$ & Rejected \\
\hline Female & 422 & 22.72 & 5.08 & & &
\end{tabular}

determination towards online learning during the COVID-19 pandemic. These hindrances include lecturers' inability to develop online courses, the high cost of data subscriptions to explore online learning materials, and distractions when learning online.

\section{Hypothesis 1}

Hypothesis 1 is the University of Port Harcourt student-teachers level of self-determination towards learning online did not vary significantly during the COVID-19 pandemic based on study year. Table 3 depicts the Welch test on student-teachers' level of selfdetermination towards learning online during the COVID-19 pandemic based on study year. Table 3 shows that the $0.00 \mathrm{p}$-value is lower than the 0.05 alpha level; this led to the rejection of the hypothesis that the University of Port Harcourt student-teachers' level of selfdetermination towards learning online did not vary significantly during the COVID-19 pandemic based on study year. Thus, the University of Port Harcourt student-teachers' level of self-determination towards learning online varies significantly, during the COVID-19 pandemic based on study year with student-teachers in year three (3) and year two (2) study year having the highest (24.63 mean value) and lowest (a 22.38 mean value) levels of self-determination towards learning online, respectively.

\section{Hypothesis 2}

Hypothesis 2 states that the University of Port Harcourt studentteacher extent of self-determination towards learning online did not vary significantly during the COVID-19 pandemic based on department. Table 4 demonstrates the Welch test on student-teachers' level of self-determination towards learning online during the COVID19 pandemic based on department. Table 4 indicates that the $0.00 \mathrm{p}$ value is lower than the 0.05 alpha level; this led to the rejection of the hypothesis that the University of Port Harcourt student-teachers' level of self-determination towards learning online did not vary significantly during the COVID-19 pandemic based on department. Thus, the University of Port Harcourt student-teachers' level of selfdetermination towards learning online varies significantly, during the COVID-19 pandemic based on departments with student-teachers in Library and Information Science Department (LIS) and Early Childhood and Primary Education (ECPE) having the highest (27.92 mean value) and lowest (a 21.09 mean value) levels of selfdetermination towards learning online, respectively.

\section{Hypothesis 3}

Hypothesis 3 is the University of Port Harcourt student-teachers level of self-determination towards learning online did not vary significantly during the COVID-19 pandemic based on gender. Table 5 shows t-test analysis of student-teachers' level of self-determination towards learning online during the COVID-19 pandemic based on gender. Table 5 reveals that the $0.00 \mathrm{p}$-value is lower than the 0.05 alpha level leading to the rejection of the hypothesis that the University of Port Harcourt student-teachers' level of self-determination towards learning online did not vary significantly during the COVID-19 pandemic based on gender. The University of Port Harcourt studentteachers' level of self-determination towards learning online varies significantly, during the COVID-19 pandemic based on gender, with the male student-teachers having the highest level of self-determination towards learning online.

\section{Hypothesis 4}

Hypothesis 4 states that the University of Port Harcourt studentteachers' self-determination hindrances to learning online did not vary significantly during the COVID-19 pandemic based on study year. Table 6 depicts the Welch test on student-teachers' level of selfdetermination hindrances to learning online during the COVID-19 
Table 6. Welch test on student-teachers' level of self-determination hindrances to learning online during the COVID-19 pandemic on study year

\begin{tabular}{|c|c|c|c|c|c|c|c|c|}
\hline Study year & $\mathbf{n}$ & Mean & S. dev. & Statistics $^{\mathbf{a}}$ & df1 & df2 & p-value & Decision \\
\hline YR 1 & 137 & 19.83 & 3.984 & \multirow{5}{*}{5.869} & \multirow{5}{*}{3} & \multirow{5}{*}{262.362} & \multirow{5}{*}{0.001} & \multirow{5}{*}{ Rejected } \\
\hline YR 2 & 270 & 21.61 & 4.953 & & & & & \\
\hline YR 3 & 80 & 20.23 & 3.656 & & & & & \\
\hline YR 4 & 125 & 20.34 & 4.429 & & & & & \\
\hline Total & 612 & 20.77 & 4.542 & & & & & \\
\hline
\end{tabular}

${ }^{\mathrm{a}}$ Asymptotically F distributed

Table 7. Welch test on student-teachers' level of self-determination hindrances to learning online during the COVID-19 pandemic on department

\begin{tabular}{|c|c|c|c|c|c|c|c|c|}
\hline Department & $\mathbf{n}$ & Mean & S. dev. & Statistics $^{\mathrm{a}}$ & df1 & df2 & p-value & Decision \\
\hline LIS & 52 & 19.54 & 3.171 & \multirow{8}{*}{10.422} & \multirow{8}{*}{6} & \multirow{8}{*}{251.520} & \multirow{8}{*}{0.00} & \multirow{8}{*}{ Rejected } \\
\hline DAE & 88 & 21.07 & 4.835 & & & & & \\
\hline EDC & 104 & 20.24 & 3.764 & & & & & \\
\hline EDP & 72 & 20.94 & 4.547 & & & & & \\
\hline EDM & 100 & 19.90 & 4.317 & & & & & \\
\hline EDF & 110 & 19.75 & 4.574 & & & & & \\
\hline ECPE & 86 & 24.05 & 4.571 & & & & & \\
\hline Total & 612 & 20.77 & 4.542 & & & & & \\
\hline
\end{tabular}

${ }^{\mathrm{a}}$ Asymptotically F distributed

Table 8. t-test analysis of student-teachers' self-determination hindrances to learning online during the COVID-19 pandemic based on gender

\begin{tabular}{ccccccccc}
\hline Gender & $\mathbf{n}$ & Mean & S. dev. & $\begin{array}{c}\text { Mean } \\
\text { difference }\end{array}$ & df & t & p-value & Decision \\
\hline Male & 190 & 20.58 & 4.248 & -0.28 & 610 & -0.71 & $\mathbf{0 . 4 8}$ & Accepted \\
\hline Female & 422 & 20.86 & 4.671 & & & & &
\end{tabular}

pandemic based on study year. Table 6 reveals that the $0.001 \mathrm{p}$-value is lower than the 0.05 alpha level. The hypothesis that the University of Port Harcourt student-teachers' self-determination hindrances to learning online did not vary significantly during the COVID-19 pandemic based on study year is rejected and the alternative accepted. Thus, the University of Port Harcourt student-teachers' selfdetermination hindrances to learning online vary significantly during the COVID-19 pandemic based on study year with student-teachers in year two (2) and year one (1) study year having the highest (21.61 mean value) and lowest (a 19.83 mean value) hindrances to learning online, respectively.

\section{Hypothesis 5}

Hypothesis 5 states that the University of Port Harcourt studentteachers' self-determination hindrances to learning online did not vary significantly during the COVID-19 pandemic based on department. Table 7 shows the Welch test on student-teachers' level of selfdetermination hindrances to learning online during the COVID-19 pandemic based on department. Table 7 unveils that the $0.00 \mathrm{p}$-value is lower than the 0.05 alpha level leading to the rejection of the hypothesis that the University of Port Harcourt student-teachers' selfdetermination hindrances to learning online did not vary significantly during the COVID-19 pandemic based on department. Thus, the University of Port Harcourt student-teachers' self-determination hindrances to learning online vary significantly, during the COVID-19 pandemic based on the department with student-teachers in Early Childhood and Primary Education (ECPE) and Library and Information Science Department (LIS) having the highest (24.05 mean value) and lowest (19.54 mean value) self-determination hindrances to learning online, respectively.

\section{Hypothesis 6}

Hypothesis 6 is the University of Port Harcourt student-teachers' self-determination hindrances to learning online did not vary significantly during the COVID-19 pandemic based on gender. Table 8 depicts the t-test analysis of student-teachers' self-determination hindrances to learning online during the COVID-19 pandemic based on gender. Table 8 discloses that the $0.48 \mathrm{p}$-value is higher than the 0.05 alpha level leading to the acceptance of the hypothesis that the University of Port Harcourt student-teachers' self-determination hindrances to learning online did not vary significantly during the COVID-19 pandemic based on gender.

\section{DISCUSSION OF THE FINDINGS}

Table 1 revealed that the student-teachers' level of selfdetermination towards learning online during the COVID-19 pandemic at the University of Port Harcourt was high. They were selfdetermined to pursue their set career goals by learning online, participate in online learning activities, and complete any online learning course they enrolled in. Their online academic pursuit was their proirty. They explored different online materials to support their learning and their online study habit increased during the COVID-19 pandemic. The student-teachers collaborated online with their course mates to solve course-related problems; however, they were unable to communicate online with their lecturers. These affirmed that the online learning was the viable option for students to learn during a pandemic and the student-teachers utilized that opportunity to increase their knowledge by being determined to learn by themselves without the support of their lecturers. Batmang et al. (2021), Balakrishnan and Long (2020), and Gustiani (2020) findings showed that students self- 
determination and their intrinsic motivation led to participation in online learning during COVID-19 pandemic agree with the present finding. However, Agbejule et al.'s (2021) findings which revealed that students' online learning participation was externally motivated by the use of online delivery mode and the fear of others leaving them behind; disagrees with this finding.

Table 2 disclosed that the University of Port Harcourt participated in online education during the COVID-19 pandemic, and most lecturers created online platforms for class communication and collaboration. The student-teachers were familiar with online learning platforms and liked participating in online learning; however, the hindrances that affected their self-determination towards online learning during the COVID-19 pandemic were most lecturers' inability to develop online courses, high cost of data subscription to explore online learning materials and distractions during learning online. This result affirmed that most University of Port Harcourt lecturers created and used only social media as online platforms to post class information and assignments, and allowed the student-teachers to share ideas among themselves, without creating course content and delivery instructions via the online learning platforms, possibly because the lecturers were incompetent to develop and deliver courses online. Also, the University of Port Harcourt student-teachers are still learning in an environment without free or subsidized Internet subscriptions, and they allowed environmental and online distractions to interfere with their online studies. Agbejule et al. (2021), Mbunge et al. (2021), Onyema et al. (2020), and Sari and Nayir's (2020) findings, which revealed, among others, that poor Internet access, technical skills, lecturers' online teaching competency, students' discipline, and social interaction were online learning challenges during the COVID-19 pandemic agreed with the present finding.

Table 3, Table 4, and Table 5 showed that the University of Port Harcourt student-teachers' self-determination level towards learning online varies significantly during the COVID-19 pandemic based on their study years, departments, and gender, respectively. These results indicate that some student-teachers, especially the year three, Library and Information Science Department, and male student-teachers, attached great values to studies and were self-determined to learning online during the COVID-19 pandemic.

Table 6, Table 7, and Table 8 unveiled that the University of Port Harcourt student-teachers' self-determination hindrances to learning online vary significantly based on their study years and departments but did not vary significantly based on gender, respectively, during the COVID-19 pandemic. Therefore, the University of Port Harcourt student-teachers in their different study years (especially, the year two student-teachers) and departments (especially, the Early Childhood and Primary Education Department) experienced more hindrances in their self-determination to learning online than others, irrespective of their gender.

\section{CONCLUSIONS AND RECOMMENDATIONS}

This study centered on the University of Port Harcourt studentteachers' self-determination level and hindrances towards learning online during the COVID-19 era. From the findings, the studentteachers' self-determination level to learning online during COVID-19 was high, although, this varies significantly based on study years, departments and gender. The student-teachers experienced some hindrances that affected their online learning self-determination. These hindrances vary significantly according to the student-teachers' study years and departments but were insignificant on a gender basis.

This study clarified that most University of Port Harcourt studentteachers were self-determined to making their online learning their priority during the COVID-19 pandemic, despite the hindrances they experienced while learning online. If these hindrances are addressed and taken care of, all the student-teachers will be more enthusiastic, intrinsically motivated, and self-determined to learning online amid any pandemic notwithstanding the study year, department, or gender.

The recommendations from the findings include the followings:

1. The University of Port Harcourt lecturers should create compulsory online interactions and communication sessions with students.

2. The University of Port Harcourt should train its lecturers to develop engaging and interactive online courses and deliver them through Learning Management Systems dedicated solely to online learning purposes.

3. Schools and government should provide free and unlimited data subscriptions for the lecturers and students.

4. Students should dedicate time to their online studies and avoid any distractions to their studies.

5. There should be future research on the effect of online learning platforms on students' self-determination.

Author contributions: All authors were involved in concept, design, collection of data, interpretation, writing, and critically revising the article. All authors approve final version of the article.

Funding: The authors received no financial support for the research and/or authorship of this article.

Declaration of interest: Authors declare no competing interest.

Data availability: Data generated or analysed during this study are available from the authors on request.

\section{REFERENCES}

Agbejule, A., Ndzibah, E., \& Lotchi, K. (2021). Motivation and barriers of online learners in the era of COVID-19. A perspective of study in Vaasa Universities. https://www.theseus.fi/bitstream/handle/10024/4292 34/978-952-5784-46-6_\%282\%29.pdf? sequence=1\&isAllowed=y

Alli, Y. (2020). Minister to varsities: Restart session through virtual teaching. Available at: https://thenationonlineng.net/minister-to-varsitiesrestart-session-through-virtual-teaching/

Balakrishnan, B., \& Long, C. Y. (2020). An effective self-directed personalized learning environment for engineering students during the COVID-19 pandemic. Advances in Engineering Education, 8(4), 18.

Bates, T. (2016). Online learning for beginners: What is online learning? https://www.tonybates.ca/2016/07/15/online-learning-forbeginners-1-what-is-online-learning/

Batmang, B., Sultan, M., Azis, A., \& Gunawan, F. (2021). Perceptions of pre-service teachers on online learning during the COVID-19 pandemic. International Journal of Education in Mathematics, Science, and Technology, 9(3), 449-461. https://doi.org/10.46328/ijemst. 1595 
College SA. (2017). Online learning. https://www.colleges.co.za/onlinelearning

Gustiani, S. (2020). Students' motivation in online learning during COVID-19 pandemic era: A case study. Holistics Journal, 12(2), 2340.

Mbunge, E., Fashoto, S. G., \& Olaomi, J. (2021). COVID-19 and online learning: Factors influencing students' academic performance in first-year computer programming courses in higher education. SSRN Electronic Journal. https://doi.org/10.2139/ssrn.3757988

National Deaf Center on Postsecondary Outcomes (NDC). (2020). Decide, act, believe: How to assess and empower self-determination in deaf youth. Available at: https://www.nationaldeafcenter.org/news/ decide-act-believe-how-assess-and-empower-self-determinationdeaf-youth

Nissman, C. (2020). 4 self-determination skills to build during remote instruction. Available at: https://districtadministration.com/4-selfdetermination-skills-to-build-during-remote-instruction/

NOVA Southeastern University. (2020). Massive online open courses (MOOC): History of MOOC. https://nsufl.libguides.com/c.php?g=11 $2312 \& \mathrm{p}=725994$
Onyema, E. M., Nwafor, C. E., Obafemi, F. A., Sen, S., Atonye, F. G., Sharma, A., \& Alsayed, A. O. (2020). Impact of Coronavirus pandemic on education. Journal of Education and Practice, 11(13), 108-121. https://doi.org/10.7176/JEP/11-13-12

Sari, T., \& Nayir, F. (2020). Challenges in distance education during the (COVID-19) pandemic period. Qualitative Research in Education, 9(3), 328-360. https://doi.org/10.17583/qre.2020.5872

Sivrikova, N., Chernikova, E., Kharlanova, E., Ptashko, T., Perebejnos, A., \& Ryabykh, I. (2021). Study of student's self-isolation adaptation strategies during the COVID-19 pandemic. BIO Web of Conferences, 29, 01001. https://doi.org/10.1051/bioconf/20212901001

UNESCO. (2020). The futures of education after COVID-19 regional dialogue synthesis report. https://en.unesco.org/sites/default/ files/synthesis_report_future_of_education_webnair_1.pdf

Vialu, C. (2018). Enhancing self-determination: Strategies to incorporate in our interventions. https:/www.seekfreaks.com/index.php/2018/ 09/27/enhancing-self-determination-strategies-to-incorporatein-our-interventions/ 
APPENDIX A

Test of homogeneity of variances for hypothesis 1

\begin{tabular}{|c|c|c|c|}
\hline \multicolumn{4}{|c|}{ Test of homogeneity of variances for hypothesis 1} \\
\hline Levene statistics & df1 & df2 & Sig. \\
\hline 8.526 & 3 & 608 & 0.000 \\
\hline \multicolumn{4}{|c|}{ Test of homogeneity of variances for hypothesis 2} \\
\hline Levene statistics & df1 & df2 & Sig. \\
\hline 3.271 & 6 & 605 & 0.004 \\
\hline \multicolumn{4}{|c|}{ Test of homogeneity of variances for hypothesis 4} \\
\hline Levene statistics & df1 & $\mathrm{df} 2$ & Sig. \\
\hline 7.195 & 3 & 608 & 0.000 \\
\hline \multicolumn{4}{|c|}{ Test of homogeneity of variances for hypothesis 5} \\
\hline Levene statistics & df1 & $\mathrm{df} 2$ & Sig. \\
\hline 2.213 & 6 & 605 & 0.040 \\
\hline
\end{tabular}

